\title{
Factors Underlying the Adoption of Social Network: A Study of Facebook Users in South Korea
}

\author{
Somkiat Mansumitrchai ${ }^{1}$, Choo-Hui Park ${ }^{1} \&$ Candy Lim Chiu ${ }^{2}$ \\ ${ }^{1}$ Keimyung University, Daegu, South Korea \\ ${ }^{2}$ ALHOSN University, Abu Dhabi, United Arab Emirates \\ Correspondence: Choo-Hui Park, Keimyung University, Daegu, South Korea. Tel: 82-53-580-6757. E-mail: \\ shineforeverjp@gmail.com
}

$\begin{array}{cc}\text { Received: September 6, } 2012 & \text { Accepted: October 18, } 2012 \quad \text { Online Published: November 28, } 2012 \\ \text { doi:10.5539/ijbm.v7n24p138 } & \text { URL: http://dx.doi.org/10.5539/ijbm.v7n24p138 }\end{array}$

This research was funded by BISA grant from Keimyung University.

\begin{abstract}
This paper examined the adoption and the uses of social network site (SNS) namely Facebook in South Korea. The aim of the study is to explore the factors contributing to the adoption and the uses of social network. The paper uses both qualitative and quantitative approaches for research methodology. The qualitative method is used to gain insight into how consumers value social network by interviewing both users and non-users. Thirty-five questions were developed in the questionnaire based on the interview.

Factor Analysis suggested nine characteristics of the adoption, namely involvement, usefulness, usage, trust, convenience, openness of information, audience, making contacts, and acceptability. A MANOVA test showed that there were significant difference on the attributes of the adoption by gender and ages. ANOVA showed that males and females differed on their attitudes toward five attributes of the adoption: involvement, usefulness, usage, openness of information, and audience. It also showed that different ages of people differed on their attitudes toward five attributes of the adoption: involvement, usefulness, usage, convenience, and openness of information. The paper indicated that Korean consumers get involved, perceive usefulness, use, and accept social network as a part of their life styles. Marketing managers should be aware of the opportunities to utilize the usefulness of social network, which may provide an avenue for companies to reach their customers more effectively.
\end{abstract}

Keywords: social network, facebook, adoption, Korean consumers, factor analysis, South Korea

\section{Introduction}

Social network has become a part of society in the digital world economy recently. The number of people around the world using social network sites (SNS) such Facebook and Cyworld has been dramatically increased every year. What motivated people to use social network has been an interesting not only in business but also in academic field as well. People are motivated to get involved in social network sites for a number of reasons. Making new friends, communicating, and connecting to other people are one of the prime reasons for using social networks (Donath \& Boyd, 2004; Lenhart \& Madden, 2007; Sheldon, 2008).

Many previous studies investigated the Internet uses and SNS adoption. Whether there was a systematic difference between people who used SNS and those who did not use, a study found that using a particular SNS was not randomly distributed among internet users (Hargittai, 2008). Many studies found that gender played a role in the internet uses (Bimber, 2000; Ono \& Zavodny, 2003; Hargittai \& Shafer, 2006). Factors such as socioeconomic status have also been shown to predict the types of Internet uses (Howard, Rainie, \& Jones, 2001; Madden \& Rainie, 2003; Livingstone \& Helsper, 2007). Walkins (2009) also found that ethnicity played a role in SNS adoption. However, to date, little research has explored in details the characteristics of the adoption of Facebook especially in South Korea. Understanding what drives SNS adoption among Koreans consumers will help to fill the gap in the literature.

The aim of this paper is to explore the factors contributing to the adoption and the uses of social network site 
(SNS) in South Korea. The first objective of the study is to examine South Korean consumer perceptions toward the adoption of social network. The second objective is to identify the factors that explained their perceptions toward social network. Demographics, gender and age, were investigated whether they played an important role in the adoption. The adoption of social network site (SNS) has been studied widely by previous studies including the differences among users and non-users of using SNS (Hargittai \& Litt, 2011), the gains and harms from the use of SNS (Stafford, 2006), the role in identity structure (Boyd, 2008), and the privacy concerns (Gross \& Acquisi, 2005; Hodge, 2006). Demographic factor has also played an important role in SNS usage. Previous studies investigated the impacts of demographics such as gender on the SNS adoption (Bimber, 2000; Jackson, Ervin, Gardner, \& Schmitt, 2001; Ono \& Zavodny, 2003; Hargittai \& Shafer, 2006), age (Lin, Chiu, \& Lim, 2011) and socioeconomic status (Howard, Rainie, \& Jones, 2001; Madden \& Rainie, 2003; Livingstone \& Helsper, 2007). Hargittai (2008) looked at the predictors of SNS usage among a diverse group of young adults. His study showed that a person's gender, race and ethnicity, and parental educational background were all associated with use. The study also showed that people with more experience and autonomy of use were more likely to be users of SNS. However, a study showed that there was no significant difference in terms of the educational level and innovativeness of the respondents between adopters and non-adopters of SNS (Lin, Chiu, \& Lim, 2011).

The motives and uses of SNS were examined from many previous studies. Social networks serve a number of functions in offline life such as providing social and emotional support (Joinson, 2008). In addition, online social networking sites also provide a number of other purposes such as social searching and social browsing (Donath \& Boyd, 2004). Other purposes included keeping in touch with friends, connecting or making new contacts, communication, sharing photos and videos, encouraging group interactions through chat rooms among SNS users. Factors affecting the adoption of SNS were investigated by many scholars. One study found that innovation characteristics (relative advantage, compatibility, and complexity) and perceived popularity differed significance among adopter categories (Lin, Chiu, \& Lim, 2011). Their study showed that the adoption of SNSs was positively related to perceived relative advantage, compatibility, and complexity.

The study also indicated that as for perceived popularity, people were more likely to adopt SNSs when their social contacts were also using them. Previous studies showed that the successful adoption of technologies depended on the perceived ease of use (Davis, Bagozzi, \& Warshaw, 1989) and Internet self-efficacy for Internet technologies (Daugherty, Eastin, \& Gangadharbatla, 2005). Gender plays a role on the uses of computer (Hall \& Cooper, 1991) and social network sites (DiMaggio, Hargittai, Celeste, \& Shafer, 2004; Livingstone \& Helsper, 2007; Mossberger, Tolbert, \& Stansbury, 2003; van Dijk, 2005). These studies found that the context of the internet uses, the level of experience, the background of characteristics of people influenced the types of Web uses in general. Using gender and age as variables, Hargittai (2008) found that gender, not age, affected the aggregate SNS usage. Women were more likely to use services from SNS than were men. However, there was a little difference between young women and young men in the SNS usage. This paper examined whether gender and age played a role in SNS. Unlike previous studies, this study focused on how gender and age differed on the basis of respondents' opinions toward using SNS on the factors derived from factor analysis.

H1: Males and females differed on the basis of their opinions toward using Facebook on involvement (H1a), usefulness (H1b), usage (H1c), trust (H1d), convenience (H1e), openness of information (H1f), audience (HIg), making new contacts (HIh), and acceptability (H1i).

H2: People with different ages differed on the basis of their opinions toward using Facebook on involvement (H2a), usefulness (H2b), usage (H2c), trust (H2d), convenience (H2e), openness of information (H2f), audience $(H 2 g)$, making new contacts (H2h), and acceptability (H2i).

\section{Method}

\subsection{Research Design}

There were two stages for developing questionnaires. Both qualitative and quantitative methods were used for theses stages.

\section{Stage 1: Qualitative Method}

To reveal what motivated people to use social network to communicate with other people such as friends and relatives, the study used an interview for this purpose. This approach would help understand the motivation and perception of using social network. In addition, it helped to identify some latent variables which might be unique in Korea and also to capture some motivations not presented in previous studies. In this case, the interview included both users and non-users of social network. The guidelines for the interviews were used for the scope of the study. The followings were the list of the questions for the interview: 
1) Why did you use social network for such as Facebook?

2) What did motivate you to use Facebook?

3) What uses of Facebook were most important to you?

4) Were there other social network did you prefer to use instead of using Facebook? What were they?

5) What were the benefits of using a social network?

From the interviews, opinions toward of using Facebook were derived. There were almost one hundred reasons why people use Facebook. To eliminate redundancy of the opinions among respondents, thirty-five reasons why people use Facebook from the list were selected and used for the questionnaires in the next stage. Table 1 presents the most mentioned of the respondents' opinion toward of using Facebook from the interview.

Table 1. Respondents' opinion toward of using Facebook

1. I am willing to share personal information in Facebook.

2. Information shared in Facebook is reliable.

3. I have time to use Facebook.

4. Meeting new friends in Facebook is good way to socialize.

5. It's interesting to make friends from other countries.

6. There's privacy in Facebook.

7. Using Facebook is safe and secured.

8. Using Facebook is acceptable in my religion.

9. Using Facebook is entertaining.

10. I know how to use Facebook.

11. Facebook is user friendly (more convenient) than other form of social network.

12. Facebook is user friendly (more convenient) than other form of communication/media.

13. Facebook can cause problems for the user. (Negative)

14. I like face-to-face communication than using internet.

15. I prefer to keep my personal information only with my friends.

16. I will use Facebook if my family and relatives are using Facebook.

17. I prefer to keep my personal information only with my relatives.

18. I like sharing photos.

19. I like sharing videos.

20. I like downloading photos and videos in Facebook.

21. It's a way to keep in touch with old friends.

22. It's interesting to check other's status and information.

23. It is ethical to use Facebook.

24. Facebook is a form of interaction with the society, community and events.

25. Facebook is only for young people.

26. Facebook can harm (establish) the relationship (couples/friends).

27. Facebook is part of my everyday activity.

28. Facebook lets you connect with you family, friends and relatives.

29. People using Facebook are trustworthy.

30. Facebook is useful.

31. Facebook is a way to express myself.

32. There's benefit using Facebook.

33. I enjoy chatting with people.

34. It's a trend to use Facebook.

35. I will use Facebook if my friends are using it. 


\section{Stage 2: Quantitative Method}

The final questionnaire included thirty-five questions, which were used and distributed to targeted samples. There were evidences that the users of new technology such as media were more likely to be young and educated; thus, students were the targeted sample for this study. The students from three major different schools, international business, social science, and business, were the respondents for the study. A non-probability method were used, thus the survey was conducted on the convenience of the sample. Three hundred questionnaires were sent to the targeted sample and 280 questionnaires were returned. About three questionnaires were not used because of the errors. Thus, the response rate was 94 percent.

\subsection{Participants and Sampling Procedures}

Participants were 238 Facebook users identified by the questionnaire. Participant were 129 males (46.6\%) and 145 females $(52.3 \%)$. The ages of respondents between 18 to 23 were $137(49.4 \%)$. Those who were above 23 were $140(50.5 \%)$. The majority of the respondents were undergraduate students $(n=262,95.3 \%)$. About $42.2 \%$ of the sample had no income. About $56.84 \%$ of the respondents knew Facebook more than one year as shown in Table 2.

Table 2. Profile of respondents and their uses of social network

\begin{tabular}{|c|c|c|c|c|}
\hline & Frequency & Percent & Valid Percent & Cummulative Percent \\
\hline \multicolumn{5}{|l|}{ 1. Gender } \\
\hline Male & 145 & 52.3 & 52.9 & 52.9 \\
\hline Female & 129 & 46.6 & 47.1 & 100.0 \\
\hline Missing & 3 & 98.9 & 100.0 & \\
\hline Total & 277 & & & \\
\hline \multicolumn{5}{|l|}{ 2. Age } \\
\hline $18-19$ & 7 & 2.5 & 2.5 & 2.5 \\
\hline $20-21$ & 45 & 16.2 & 16.2 & 18.8 \\
\hline $22-23$ & 85 & 30.7 & 30.7 & 49.5 \\
\hline Above 23 & 140 & 50.5 & 50.5 & 100.0 \\
\hline Total & 277 & & & \\
\hline \multicolumn{5}{|l|}{ 3. Education } \\
\hline High school & 212 & 76.5 & 79.7 & 79.7 \\
\hline Bachelor & 25 & 18.8 & 19.5 & 99.2 \\
\hline Master & 1 & 0.4 & 0.4 & 99.6 \\
\hline Doctoral & 1 & 0.4 & 0.4 & 100 \\
\hline Missing & 11 & 4.0 & & \\
\hline Total & 277 & & & \\
\hline \multicolumn{5}{|c|}{ 4. Income per month (in Korean Won) } \\
\hline Less than 500,000 & 132 & 47.7 & 47.8 & 47.8 \\
\hline $500,000-1,000,000$ & 18 & 6.5 & 6.5 & 54.3 \\
\hline $1,00,001-1,500,000$ & 3 & 1.1 & 1.1 & 55.4 \\
\hline $1,500,001-2,000,000$ & 2 & 0.7 & 0.7 & 56.2 \\
\hline $2,000,001-3,000,000$ & 4 & 1.4 & 1.4 & 57.6 \\
\hline Have no income & 117 & 42.2 & 42.4 & 100.0 \\
\hline Missing & 1 & 0.4 & & \\
\hline Total & 277 & & & \\
\hline \multicolumn{5}{|c|}{ 5. Using the Internet } \\
\hline Less tha 6 months & 3 & 1.1 & 1.1 & 1.1 \\
\hline $1-3$ years & 2 & 0.7 & 0.7 & 1.8 \\
\hline 4-6 years & 10 & 3.6 & 3.6 & 5.7 \\
\hline 7 years or more & 261 & 94.2 & 94.2 & 99.6 \\
\hline Missing & 1 & 0.4 & 0.4 & 100.0 \\
\hline Total & 277 & & & \\
\hline
\end{tabular}




\begin{tabular}{|c|c|c|c|c|}
\hline \multicolumn{5}{|c|}{ 6. Own Mobile Phone } \\
\hline Yes & 22 & 7.9 & 8.0 & 8.0 \\
\hline No & 254 & 91.7 & 92.0 & 100.0 \\
\hline Missing & 1 & 0.4 & & \\
\hline Total & 277 & & & \\
\hline \multicolumn{5}{|c|}{ 7. Own a laptop } \\
\hline Yes & 69 & 24.9 & 24.9 & 24.9 \\
\hline No & 208 & 75.1 & 75.1 & 100.0 \\
\hline Total & 277 & & & \\
\hline \multicolumn{5}{|c|}{ 8. Own a Smart Phone } \\
\hline Yes & 12 & 4.3 & 1.3 & 4.3 \\
\hline No & 265 & 95.7 & 95.7 & 100.0 \\
\hline Total & 277 & & & \\
\hline \multicolumn{5}{|c|}{ 9. Own Tablet } \\
\hline Yes & 257 & 92.8 & 92.8 & 92.8 \\
\hline No & 20 & 7.2 & 7.2 & 100.0 \\
\hline Total & 277 & & & \\
\hline \multicolumn{5}{|c|}{ 10. Use Facebook Recently } \\
\hline Yes & 35 & 12.6 & 12.8 & 12.8 \\
\hline No & 238 & 85.9 & 87.2 & 100.0 \\
\hline Missing & 4 & 1.4 & & \\
\hline Total & 277 & & & \\
\hline \multicolumn{5}{|c|}{ 11. How long have you known Facebook? } \\
\hline Less than 1 year & 104 & 37.5 & 43.2 & 43.2 \\
\hline $1-3$ years & 110 & 39.7 & 45.6 & 88.8 \\
\hline 4-5 years & 21 & 7.6 & 8.7 & 97.5 \\
\hline More than 5 years & 6 & 2.2 & 2.5 & 100.0 \\
\hline Missing & 36 & 13.0 & & \\
\hline Total & 277 & & & \\
\hline \multicolumn{5}{|c|}{ 12. Access Facebook (more than one choice) } \\
\hline By Smart phone & 208 & 50.60 & & \\
\hline By laptop & 104 & 25.30 & & \\
\hline By computer & 85 & 20.68 & & \\
\hline By tablet & 14 & 3.40 & & \\
\hline Total & 411 & & & \\
\hline \multicolumn{5}{|c|}{ 13. Other social network used } \\
\hline Kakao Talk & 231 & 50.76 & & \\
\hline Cyworld & 155 & 34.06 & & \\
\hline Twitter & 50 & 10.98 & & \\
\hline Others & 19 & 4.17 & & \\
\hline Total & 455 & & & \\
\hline \multicolumn{5}{|c|}{ 14. The first choice for social betwork or other media } \\
\hline Kakao Talk & 187 & 79.9 & & \\
\hline Facebook & 40 & 17.09 & & \\
\hline Cyworld & 4 & 1.70 & & \\
\hline Twitter & 1 & 0.42 & & \\
\hline Others & 2 & 0.85 & & \\
\hline Total & 234 & & & \\
\hline
\end{tabular}




\subsection{Measures}

The survey was administered on paper instead of online. Participants were asked to rate their opinion toward using Facebook on a 5-point Likert scale for thirty-five questions derived from the interviews from stage 1 . The scale was anchored at 1 (strongly disagree) and 5 (strongly agree). The survey included detailed questions about respondents' Internet experience, internet uses, SNS experience and uses, having access to social network sites, and their demographic background.

To ensure the degree of consistency among measurements of the variables, Cronbach's alpha for reliability test was performed for all thirty-five variables and the result was .880 on the standardized item. The Hotelling's T-square shows significant level with the calculated F39.967. To assess the overall significance of the correlation matrix, the Bartlett's test of sphericity was measured. The Bartlett test shows that nonzero correlations existed at the significance level of .000. The Kaiser-Meyer-Olkin (KMO) was measured for the sampling adequacy (MSA). The result demonstrates that the set of variables collectively met the necessary threshold of sampling adequacy with an MSA value of .854. Thus, the set of variables met the fundamental requirements for factor analysis.

To identify the adoption characteristics, the study used factor analysis with varimax rotation as an extraction method. The study used .60 as a cut-off point for all factor loadings suggested by Hair (1998). From factor analysis, the result suggested nine factors with eigenvalue greater than 1 as shown in (Table 3). The identified nine factors represented 60.65 percent of the total variance explained by these factors. By examining each item in each factor, the names of factors were identified.

The first factor, involvement, consisted of eight items with eigenvalue 4.087, which accounted 11.67 percent of total variance. The second factor, usefulness, was loaded with three items with eigenvalue 3.104 ( 8.87 percent of variance). The third factor, usage, contained three items with eigenvalue 2.708 ( 7.73 percent of variance). The forth factor namely trust included two items with the eigenvalue 2.587 (7.39 percent of variance). The fifth factor, convenience, consisted of two items with the eigenvalue 2.352 (6.72 percent of variance). The sixth factor namely openness of information contained two items with the eigenvalue 1.909 (5.45 percent of variance). The seventh factor labeled as audience was loaded with one item with the eigenvalue 1.563 (4.46 percent of variance). The eighth factor, making new contacts, included two items with the eigenvalue 1.552 (4.43 percent of variance). The last factor namely acceptability contained two items with the eigenvalue 1.367 (3.90 percent of variance).

Table 3. Factor underlying adoption characteristics

\begin{tabular}{|c|c|c|c|c|c|c|c|c|c|}
\hline & F1 & F2 & F3 & F4 & F5 & F6 & F7 & F8 & F9 \\
\hline \multicolumn{10}{|l|}{ Factor 1: Involvement } \\
\hline 1. I have time to use Facebook. & .65 & & & & & & & & \\
\hline $\begin{array}{l}\text { 2. I will use Facebook if my family and relatives } \\
\text { are using Facebook. }\end{array}$ & .67 & & & & & & & & \\
\hline 3. Facebook is part of my everyday activity. & .64 & & & & & & & & \\
\hline 4. I will use Facebook if my friends are using it. & .79 & & & & & & & & \\
\hline \multicolumn{10}{|l|}{ Factor 2: Usefulness } \\
\hline $\begin{array}{l}\text { 1. Facebook is a form of interaction with the } \\
\text { society, community, and events. }\end{array}$ & & .64 & & & & & & & \\
\hline 2. Facebook is useful. & & .67 & & & & & & & \\
\hline 3. It is a trend to use Facebook. & & .60 & & & & & & & \\
\hline \multicolumn{10}{|l|}{ Factor 3: Usage } \\
\hline 1. I like sharing photos. & & & .69 & & & & & & \\
\hline 2. I like sharing videos. & & & .84 & & & & & & \\
\hline 3. I like downloading photos and videos. & & & .71 & & & & & & \\
\hline \multicolumn{10}{|l|}{ Factor 4: Trust } \\
\hline 1. Using Facebook is safe and secured. & & & & .77 & & & & & \\
\hline 2. People using Facebook are trustworthy. & & & & .67 & & & & & \\
\hline
\end{tabular}


Factor 5: Convenience

1. Facebook is user friendly (more convenient) than other form of social network.

2. Facebook is user friendly (more convenient) than other form of communication/media.

Factor 6: Openness of information

1. I prefer to keep my personal information only with my friends.

2. I prefer to keep my personal informarion only with my relatives.

Factor 7: Audience

1. Facebook is only for young people.

Factor 8: Making new contacts

1. Meeting new friends in Facebook is a good way to socialize.

2. It is interesting to make friends from other countries.

Factor 9: Acceptability

1. Using Facebook is acceptable in my religion.

2. Facebook can harm the relationship (couples/friends).

Eigen values

\begin{tabular}{ccccccccc}
4.08 & 3.10 & 2.70 & 2.58 & 2.35 & 1.90 & 1.56 & 1.55 & 1.36 \\
11.67 & 8.87 & 7.73 & 7.39 & 6.72 & 5.45 & 4.46 & 4.43 & 3.90 \\
11.67 & 20.54 & 28.28 & 35.67 & 42.39 & 47.84 & 52.31 & 56.75 & 60.65 \\
0.869 & 0.871 & 0.871 & 0.875 & 0.871 & 0.88 & 0.884 & 0.876 & 0.878 \\
\hline
\end{tabular}

Lastly, an internal consistency evaluation was performed by measuring the item-to-total correlation (the correlation of the item to the summated scale score). Inter-item correlations within each summated scale score (the correlations among items) were also measured. The rule of thumb was that the scale was considered reliable when the internal consistency for the item-to-total correlation was above .50 and the inter-item correlation was above .30 (see Hair et al., 1998). All the correlations of the items to the summated scale scores were above .50 (at the .01 level) and all the inter-item correlations within each summated score were above .30 (at the .01 level). Thus, the items used for each construct met the requirements of reliability.

\section{Results}

\subsection{MANOVA}

A MANOVA test showed a significant difference between males and females on their scores across nine factors (involvement, usefulness, usage, trust, convenience, openness of information, audience, making contacts, acceptability). All statistical tests, Wilk's Lambda, Hotelling's Trace, and Roy's Largest Root, were significant (p $<.05$ ). Also, A MANOVA test showed a significant difference between the ages (below 23 and above 23) on the scores across nine factors. All statistical results, Wilk's Lambda, Hotelling's Trace, and Roy's Largest Root, were significant $(\mathrm{p}<.05)$. Table 4 and 5 shows that comparisons of the mean scores and standard deviations across nine factors on gender and age variables. 
Table 4. A comparison of factors on gender variable

\begin{tabular}{|c|c|c|c|c|c|c|}
\hline \multirow[t]{2}{*}{ Factors } & \multicolumn{2}{|c|}{ All } & \multicolumn{2}{|c|}{ Males } & \multicolumn{2}{|c|}{ Females } \\
\hline & Mean & Std & Mean & Std & Mean & Std \\
\hline Involvement & 3.42 & .820 & 3.32 & .832 & 3.50 & .802 \\
\hline Usefulness & 3.65 & .608 & 3.53 & .654 & 3.75 & .547 \\
\hline Usage & 3.14 & .791 & 3.05 & .857 & 3.21 & .723 \\
\hline Trust & 2.38 & .661 & 2.42 & .637 & 2.34 & .681 \\
\hline Convenience & 3.39 & .783 & 3.32 & .856 & 3.45 & .710 \\
\hline Openness of Information & 3.31 & .794 & 3.21 & .770 & 3.39 & .807 \\
\hline Audience & 2.59 & 1.052 & 2.45 & 1.013 & 2.71 & 1.073 \\
\hline Making New Contacts & 3.35 & .744 & 3.36 & .718 & 3.34 & .768 \\
\hline Acceptability & 3.50 & .689 & 3.48 & .687 & 3.51 & .692 \\
\hline
\end{tabular}

Note: 5 indicates strongly agree and I indicates strongly disagree on the likert scale.

Table 5. A comparison of factors on age variable

\begin{tabular}{lcccccc}
\hline \multirow{2}{*}{ Factors } & \multicolumn{3}{c}{ All } & \multicolumn{2}{c}{$>23$ years } & \multicolumn{2}{c}{$<2$ years } \\
\cline { 2 - 7 } & Mean & Std & Mean & Std & Mean & Std \\
\hline Involvement & 3.41 & .817 & 3.29 & .863 & 3.53 & .751 \\
Usefulness & 3.64 & .608 & 3.54 & .615 & 3.75 & .585 \\
Usage & 3.14 & .788 & 3.03 & .854 & 3.24 & .705 \\
Trust & 2.38 & .659 & 2.39 & .689 & 2.38 & .631 \\
Convenience & 3.39 & .784 & 3.30 & .809 & 3.47 & .751 \\
Openness of Information & 3.30 & .790 & 3.20 & .796 & 3.41 & .772 \\
Audience & 2.59 & 1.051 & 2.58 & 1.031 & 2.61 & 1.073 \\
Making New Contacts & 3.35 & .741 & 3.39 & .690 & 3.31 & .789 \\
Acceptability & 3.49 & .692 & 3.51 & .702 & 3.47 & .684 \\
\hline
\end{tabular}

Note: 5 indicates strongly agree and I indicates strongly disagree on the likert scale.

\subsection{ANOVA}

To test the hypotheses, an analysis of variance (ANOVA) was used to compare the means of the nine factors (involvement, usefulness, usage, trust, convenience, openness of information, audience, making contacts, and acceptability). For the first hypothesis, the ANOVA results show that there were significant differences on the perceptions toward the adoption between males and females on five factors: involvement $(\mathrm{F}=3.473, \mathrm{p}<.10)$, usefulness $(\mathrm{F}=9.144, \mathrm{p}<.01)$, usage $(\mathrm{F}=2.796, \mathrm{p}<.10)$, openness of information $(\mathrm{F}=3.474, \mathrm{p}<.01)$, and audience $(\mathrm{F}=4.235, \mathrm{p}<.05)$ (Table 6). For involvement factor, females had a higher score compared to that of males, suggesting that females were more involved than males in using Facebook.

The result showed that females perceived usefulness of using Facebook than males did. Females also had higher scores than males' scores on usage factor, suggesting that females preferred to share and download photos than males did. For the openness of information factor, females had higher score (mean $=3.39$ ) than males did (mean $=3.21$ ), suggesting that females preferred to keep their information personally. For the audience factor, although males and females differed on the opinions whether Facebook was only for young people, both of them neither agreed nor disagreed on their scores (mean for female $=2.71$; mean for male $=2.45$ ). The females score suggested that they agreed Facebook was for young people. Thus, these results supported the hypotheses H1a, $\mathrm{H} 1 \mathrm{~b}, \mathrm{H} 1 \mathrm{c}, \mathrm{H} 1 \mathrm{f}$, and H1g.

For the second hypothesis testing, the ANOVA results from Table 7 showed that there were significant differences on the perceptions of the adoption between different ages on five factors: involvement $(\mathrm{F}=5.923$, 
$\mathrm{p}<.05)$, usefulness $(\mathrm{F}=7.99, \mathrm{p}<.01)$, usage $(\mathrm{F}=4.53, \mathrm{p}<.05)$, convenience $(\mathrm{F}=3.264, \mathrm{p}<.10)$, and openness of information $(\mathrm{F}=5.169, \mathrm{p}<.05)$. The result showed that younger people, who were less than twenty-three, had higher scores on involvement, usefulness, usage, convenience, and openness of information. The results suggested that younger people were actively involved with using Facebook. They also found Facebook very useful and convenience, and they perceived many benefits of using social network site. However, young people preferred to keep their information for personal uses. Thus, the results supported the hypotheses H2a, H2b, H2c, $\mathrm{H} 2 \mathrm{e}$, and $\mathrm{H} 2 \mathrm{f}$.

The result showed that females perceived usefulness of using Facebook than males did. Females also had higher scores than males' scores on usage factor, suggesting that females preferred to share and download photos than males did. For the openness of information factor, females had higher score (mean $=3.39$ ) than males did (mean $=3.21$ ), suggesting that females preferred to keep their information personally. For the audience factor, although males and females differed on the opinions whether Facebook was only for young people, both of them neither agreed nor disagreed on their scores (mean for female $=2.71$; mean for male $=2.45$ ). The females score suggested that they agreed Facebook was for young people. Thus, these results supported the hypotheses H1a, H1b, H1c, H1f, and H1g. Table 8 and 9 showed the comparisons of characteristics of adoption ranked by the mean scores of gender and age variables. Table 10 summarized all the hypothesis tests.

Table 6. ANOVA on gender variable

\begin{tabular}{|c|c|c|c|c|c|c|}
\hline Factors & Groups & Sum of Square & Df & Mean Square & $\mathrm{F}$ & Sig \\
\hline \multirow[t]{3}{*}{ 1. Involvement } & Between Groups & 2.312 & 1 & 2.312 & 3.473 & $.063 *$ \\
\hline & Within Groups & 179.743 & 270 & .666 & & \\
\hline & Total & 182.055 & 271 & & & \\
\hline \multirow[t]{3}{*}{ 2. Usefulness } & Between Groups & 3.286 & 1 & 3.286 & 9.144 & $.003 * * *$ \\
\hline & Within Groups & 95.942 & 267 & .359 & & \\
\hline & Total & 99.228 & 268 & & & \\
\hline \multirow[t]{3}{*}{ 3.Usage } & Between Groups & 1.736 & 1 & 1.736 & 2.796 & $.096^{*}$ \\
\hline & Within Groups & 166.416 & 268 & .621 & & \\
\hline & Total & 168.152 & 269 & & & \\
\hline \multirow[t]{3}{*}{ 4. Trust } & Between Groups & .340 & 1 & .340 & .778 & .379 \\
\hline & Within Groups & 117.127 & 268 & .437 & & \\
\hline & Total & 117.467 & 269 & & & \\
\hline \multirow[t]{3}{*}{ 5. Covenience } & Between Groups & 1.125 & 1 & 1.125 & 1.841 & .176 \\
\hline & Within Groups & 164.926 & 270 & .611 & & \\
\hline & Total & 166.051 & 271 & & & \\
\hline \multirow{3}{*}{$\begin{array}{r}\text { 6. Openness of } \\
\text { information }\end{array}$} & Between Groups & 2.168 & 1 & 2.168 & 3.474 & $.063^{*}$ \\
\hline & Within Groups & 167.911 & 269 & .624 & & \\
\hline & Total & 170.079 & 270 & & & \\
\hline \multirow[t]{3}{*}{ 7.Audience } & Between Groups & 4.631 & 1 & 4.631 & 4.235 & $.041 * *$ \\
\hline & Within Groups & 295.252 & 270 & 1.094 & & \\
\hline & Total & 299.882 & 271 & & & \\
\hline \multirow{3}{*}{$\begin{array}{l}\text { 8. Making new } \\
\text { contacts }\end{array}$} & Between Groups & .019 & 1 & .019 & .035 & .852 \\
\hline & Within Groups & 149.801 & 270 & .555 & & \\
\hline & Total & 149.820 & 271 & & & \\
\hline \multirow[t]{3}{*}{ 9. Acceptability } & Between Groups & .035 & 1 & .035 & .073 & .787 \\
\hline & Within Groups & 127.962 & 269 & .476 & & \\
\hline & Total & 127.996 & 270 & & & \\
\hline
\end{tabular}

Note: ***significant at $\mathrm{p}<.01 ; * *$ significant at $\mathrm{p}<.05$; *significant at $\mathrm{p}<.10$ 
Table 7. ANOVA on age variable

\begin{tabular}{|c|c|c|c|c|c|c|}
\hline Factors & Groups & Sum of Square & $\mathrm{Df}$ & Mean Square & $\mathrm{F}$ & Sig \\
\hline \multirow[t]{3}{*}{ 1. Involvement } & Between Groups & 3.879 & 1 & 3.879 & 5.923 & $.016^{* *}$ \\
\hline & Within Groups & 178.795 & 273 & .655 & & \\
\hline & Total & 182.674 & 274 & & & \\
\hline \multirow[t]{3}{*}{ 2. Usefulness } & Between Groups & 2.882 & 1 & 2.882 & 7.990 & $.005^{* * *}$ \\
\hline & Within Groups & 97.399 & 270 & .361 & & \\
\hline & Total & 100.281 & 271 & & & \\
\hline \multirow[t]{3}{*}{ 3.Usage } & Between Groups & 2.776 & 1 & 2.776 & 4.530 & $.034 * *$ \\
\hline & Within Groups & 166.098 & 271 & .613 & & \\
\hline & Total & 168.874 & 272 & & & \\
\hline \multirow[t]{3}{*}{ 4. Trust } & Between Groups & .005 & 1 & .005 & .101 & .919 \\
\hline & Within Groups & 118.245 & 271 & .436 & & \\
\hline & Total & 118.249 & 272 & & & \\
\hline \multirow[t]{3}{*}{ 5.Covenience } & Between Groups & 1.989 & 1 & 1.989 & 3.264 & $.072 *$ \\
\hline & Within Groups & 166.378 & 273 & 609 & & \\
\hline & Total & 168.367 & 274 & & & \\
\hline \multirow{3}{*}{$\begin{array}{l}\text { 6.Openness of } \\
\text { information }\end{array}$} & Between Groups & 3.176 & 1 & 3.176 & 5.169 & $.024 * *$ \\
\hline & Within Groups & 167.128 & 272 & .614 & & \\
\hline & Total & 170.304 & 273 & & & \\
\hline \multirow[t]{3}{*}{ 7.Audience } & Between Groups & .047 & 1 & .047 & .042 & .837 \\
\hline & Within Groups & 302.339 & 273 & 1.107 & & \\
\hline & Total & 302.385 & 274 & & & \\
\hline \multirow{3}{*}{$\begin{array}{l}\text { 8. Making new } \\
\text { contacts }\end{array}$} & Between Groups & .537 & 1 & .537 & .978 & .324 \\
\hline & Within Groups & 149.851 & 273 & .549 & & \\
\hline & Total & 150.357 & 274 & & & \\
\hline \multirow[t]{3}{*}{ 9. Acceptability } & Between Groups & .154 & 1 & .154 & .321 & .571 \\
\hline & Within Groups & 130.573 & 272 & .480 & & \\
\hline & Total & 130.727 & 273 & & & \\
\hline
\end{tabular}

Note: ${ }^{* * *}$ significant at $\mathrm{p}<.01 ; * *$ significant at $\mathrm{p}<.05 ;{ }^{*}$ significant at $\mathrm{p}<.10$

Table 8. Comparisons of characteristics of adoption ranked by the mean scores of gender variable

\begin{tabular}{|c|c|c|c|c|c|}
\hline & Females & Males & t-stat & Df & Sig \\
\hline Q34. It is a trend to use Facebook. (Usefulness) & 4.03 & 3.68 & 3.154 & 270 & $.002 * * *$ \\
\hline $\begin{array}{l}\text { Q15. I prefer to keep my personal information } \\
\text { only with my friends. (Openness of information) }\end{array}$ & 4.01 & 3.73 & 2.350 & 270 & $.019 * *$ \\
\hline Q2. I have time to use Facebook (Involvement) & 3.98 & 3.61 & 3.12 & 270 & $.002 * * *$ \\
\hline $\begin{array}{l}\text { Q24. Facebook is a form of interaction with the } \\
\text { society, community, and events. (Usefulness) }\end{array}$ & 3.81 & 3.61 & 2.318 & 270 & $.021 * *$ \\
\hline $\begin{array}{l}\text { Q8. Using Facebook is acceptable in my religion. } \\
\text { (Acceptability) }\end{array}$ & 3.70 & 3.76 & -.573 & 270 & .567 \\
\hline $\begin{array}{l}\text { Q5. It is intesreting to make friends from other } \\
\text { countries. (Making new contacts) }\end{array}$ & 3.67 & 3.56 & 1.052 & 270 & .297 \\
\hline
\end{tabular}




\begin{tabular}{|c|c|c|c|c|c|}
\hline $\begin{array}{l}\text { Q35. I will use Facebook if my frienda are using } \\
\text { it. (Involvement) }\end{array}$ & 3.59 & 3.42 & 1.364 & 270 & .174 \\
\hline $\begin{array}{l}\text { Q11. Facebook is user freidnly more convenient } \\
\text { than other form of social network. (Convenience) }\end{array}$ & 3.58 & 3.34 & 2.166 & 270 & $.031 * *$ \\
\hline Q18. I like sharing photos. (Usage) & 3.57 & 3.19 & 3.286 & 270 & $.001^{* * *}$ \\
\hline Q30. Facebook is useful. (Usefulness) & 3.43 & 3.30 & 1.415 & 267 & .158 \\
\hline $\begin{array}{l}\text { Q12. Facebook is user friendly more convenience } \\
\text { than other form of communication/media. } \\
\text { (Convenience) }\end{array}$ & 3.32 & 3.31 & .170 & 270 & .865 \\
\hline $\begin{array}{l}\text { Q26. Facebook can harm relationship } \\
\text { (couples/friends). (Acceptability) }\end{array}$ & 3.31 & 3.20 & 1.003 & 269 & .317 \\
\hline $\begin{array}{l}\text { Q16. I will use Facebook if my family and } \\
\text { relatives are using it. (Involvement) }\end{array}$ & 3.26 & 3.19 & .600 & 270 & .549 \\
\hline $\begin{array}{l}\text { Q27. Facebook is part of my everyday activity. } \\
\text { (Involvement) }\end{array}$ & 3.18 & 3.06 & .842 & 270 & .401 \\
\hline Q19. I like sharing videos. (Usage) & 3.17 & 3.11 & .485 & 269 & .628 \\
\hline $\begin{array}{l}\text { Q4. Meeting new friends in facebook is a good } \\
\text { way to socialize. (Making new contacts) }\end{array}$ & 3.01 & 3.16 & -1.237 & 270 & .217 \\
\hline $\begin{array}{l}\text { Q20. I like downloading photos and videos in } \\
\text { facebook. (Usage) }\end{array}$ & 2.90 & 2.81 & .758 & 269 & .449 \\
\hline $\begin{array}{l}\text { Q17. I prefer to keep my personal information } \\
\text { only with my relatives. (Openness of information) }\end{array}$ & 2.77 & 2.67 & .837 & 269 & .403 \\
\hline $\begin{array}{l}\text { Q25. Facebook is only for young people. } \\
\text { (Audience) }\end{array}$ & 2.71 & 2.45 & 2.058 & 270 & $.041 * *$ \\
\hline $\begin{array}{l}\text { Q29. People using facebook are trustworthy. } \\
\text { (Trust) }\end{array}$ & 2.70 & 2.67 & .312 & 269 & .755 \\
\hline Q7. Using facebook is safe and secured. (Trust) & 1.99 & 2.19 & -1.990 & 269 & $.048 * *$ \\
\hline
\end{tabular}

Note: $* * *$ significant at $\mathrm{p}<.01 ; * *$ significant at $\mathrm{p}<.05 ; *$ significant at $\mathrm{p}<.10$

Table 9. Comparisons of characteristics of adoption ranked by the mean scores of age variable

\begin{tabular}{|c|c|c|c|c|c|}
\hline & $<23$ & Above 23 & t-stat & $\mathrm{Df}$ & Sig \\
\hline Q34. It is a trend to use Facebook. (Usefulness) & 3.99 & 3.72 & 2.419 & 273 & $.016^{* *}$ \\
\hline $\begin{array}{l}\text { Q15. I prefer to keep my personal information } \\
\text { only with my friends. (Openness of information) }\end{array}$ & 3.96 & 3.80 & 1.474 & 273 & .142 \\
\hline Q2. I have time to use Facebook (Involvement) & 3.96 & 3.63 & 2.793 & 273 & $.006^{* * *}$ \\
\hline $\begin{array}{l}\text { Q24. Facebook is a form of interaction with the } \\
\text { society, community, and events. (Usefulness) }\end{array}$ & 3.81 & 3.61 & 2.351 & 273 & $.019 * *$ \\
\hline $\begin{array}{l}\text { Q35. I will use Facebook if my frienda are using } \\
\text { it. (Involvement) }\end{array}$ & 3.66 & 3.36 & 2.426 & 273 & $.016^{* *}$ \\
\hline $\begin{array}{l}\text { Q8. Using Facebook is acceptable in my } \\
\text { religion. (Acceptability) }\end{array}$ & 3.65 & 3.80 & -1.264 & 273 & .207 \\
\hline $\begin{array}{l}\text { Q11. Facebook is user freidnly more convenient } \\
\text { than other form of social network. } \\
\text { (Convenience) }\end{array}$ & 3.61 & 3.31 & 2.656 & 273 & $.008 * * *$ \\
\hline $\begin{array}{l}\text { Q5. It is intesreting to make friends from other } \\
\text { countries. (Making new contacts) }\end{array}$ & 3.58 & 3.67 & -.872 & 273 & .384 \\
\hline Q18. I like sharing photos. (Usage) & 3.55 & 3.24 & 2.645 & 273 & $.009 * * *$ \\
\hline
\end{tabular}




\begin{tabular}{|c|c|c|c|c|c|}
\hline Q30. Facebook is useful. (Usefulness) & 3.43 & 3.29 & 1.591 & 270 & .119 \\
\hline $\begin{array}{l}\text { Q12. Facebook is user friendly more } \\
\text { convenience than other form of } \\
\text { communication/media. (Convenience) }\end{array}$ & 3.34 & 3.30 & .462 & 273 & .644 \\
\hline Q19. I like sharing videos. (Usage) & 3.30 & 3.07 & 1.184 & 272 & .238 \\
\hline $\begin{array}{l}\text { Q26. Facebook can harm relationship } \\
\text { (couples/friends). (Acceptability) }\end{array}$ & 3.28 & 3.23 & .548 & 272 & .584 \\
\hline $\begin{array}{l}\text { Q27. Facebook is part of my everyday activity. } \\
\text { (Involvement) }\end{array}$ & 3.26 & 3.96 & 2.001 & 273 & $.046^{* *}$ \\
\hline $\begin{array}{l}\text { Q16. I will use Facebook if my family and } \\
\text { relatives are using it. (Involvement) }\end{array}$ & 3.25 & 3.22 & .255 & 273 & .799 \\
\hline $\begin{array}{l}\text { Q4. Meeting new friends in facebook is a good } \\
\text { way to socialize. (Making new contacts) }\end{array}$ & 3.04 & 3.12 & -.752 & 273 & .453 \\
\hline $\begin{array}{l}\text { Q24. Facebook is a form of interaction with the } \\
\text { society, community, and events. (Usefulness). }\end{array}$ & 3.81 & 3.61 & 2.351 & 273 & $.019 * *$ \\
\hline $\begin{array}{l}\text { Q20. I like downloading photos and videos in } \\
\text { facebook. (Usage) }\end{array}$ & 2.96 & 2.75 & 1.811 & 272 & .071 \\
\hline $\begin{array}{l}\text { Q17. I prefer to keep my personal information } \\
\text { only with my relatives. (Openness of } \\
\text { information) }\end{array}$ & 2.86 & 2.58 & 2.240 & 272 & .026 \\
\hline $\begin{array}{l}\text { Q29. People using facebook are trustworthy. } \\
\text { (Trust) (Audience) }\end{array}$ & 2.66 & 2.75 & -.585 & 272 & .559 \\
\hline Q25. Facebook is only for young people. & 2.61 & 2.58 & .206 & 273 & .837 \\
\hline Q7. Using facebook is safe and secured. (Trust) & 2.10 & 2.07 & .294 & 272 & .769 \\
\hline
\end{tabular}

Note: $* * *$ significant at $\mathrm{p}<.01 ; * *$ significant at $\mathrm{p}<.05 ; *$ significant at $\mathrm{p}<.10$

Table 10. Summary of hypothesis testing

\begin{tabular}{lc}
\hline \multicolumn{1}{c}{ Hypotheses } & Results \\
\hline $1^{\text {st }}$ Hypothesis (Gender Variable) & Supported \\
Males and females differed on their opinions toward using Facebook on involvement & \\
(H1a), usefulness (H1b), usage (H1c), openness of information (H1f), audience (H1g) & Not supported \\
$1^{\text {st }}$ Hypothesis (Gender Variable) & \\
Males and females differed on their opinions toward using Facebook on trust (H1d), & \\
convenience (H1e), making new contacts (H1h), acceptability (H1i) & Supported \\
$2^{\text {nd }}$ Hypothesis (Age Variable) & \\
People with different ages differed on their opinions toward using Facebook on \\
involvement (H2a), usefulness (H2b), usage (H2c), convenience (H2e), openness of \\
information (H2f) \\
$\begin{array}{l}2^{\text {nd }} \text { Hypothesis (Age Variable) } \\
\text { People with different ages differed on their opinions toward using Facebook on trust } \\
\text { (H2d), audience (H2g), making new contacts (H2h), acceptability (H2i) }\end{array}$ \\
\hline
\end{tabular}

\section{Discussion}

This paper examined the characteristics of the adoption of SNS among Korean consumers. Nine factors include involvement, usefulness, usage, trust, convenience, openness of information, audience, making contacts, and acceptability, were identified from the study. Gender and age were tested whether there were differences on the characteristics of adoption, and the study showed the mix results. Males and females were differences on the involvement, usefulness, usage, openness of information and audience. The study showed that younger people 
were more likely to get involved in using SNS, and they perceived SNS more usefulness, usage, convenience.

\subsection{Involvement}

This study found that involvement of SNS was the most important factor among nine factors. It contributed 11.67 percent of explained variance. The results showed that people considered SNS a part of their lives and they had time to use it. One interesting findings in this study was that people were involved with the SNS when their friends or families were using the SNS. This phenomenon could be explained by being "socially dominant (Parkhurst \& Hopmeyer, 1998) and "accepted by one’s peer group members" (Bukoski \& Hoza, 1989).

\subsection{Usefulness}

The second factor found in the study was usefulness. People perceived benefits of using SNS. One of the benefits was people used Facebook as a form to interact with the society, community and events. It was consistent with the findings of previous studies that social networks have been identified in online communities and that SNS provide users with social capital (Wellman \& Gulia, 1999; Ellison, Steinfield, \& Lampe, 2006). This study also showed that users perceived that there was a trend in using Facebook. This paper found that females perceived Facebook more useful than males did. The same result was found among the younger people respondents. Both females and younger people believed that using Facebook was a trend for everyday life.

\subsection{Usage}

Number of previous studies identified the usage of SNS such as sending and receiving messages, finding people, posting and sharing pictures, viewing profile, chatting, and joining groups, etc (Joinson, 2008). The similar findings were found in this study. Users liked to share photos and videos on SNS. Females and younger people were more active than their counterparts for these activities.

\subsection{Trust}

Trust has been considered one of the most attributes of adoption especially in the electronic forms such as e-commerce or internet banking (Mansumitrchai \& Malkawi, 2011; Mansumitrchai \& Chiu, 2012). There was no exception for the SNS adoption as well. Trust is considered important factor because it can increase the rate of adoption. This study found that the questions related to trust had low mean scores (mean $=2$ from 5), indicating that users perceived some kinds of risks of using SNS. It also showed that trust was the main issue for SNS adoption regardless of gender and age.

\subsection{Convenience}

Ease of use and friendly use of SNS is also one of the most attributes in the adoption. The features of Facebook sites such as easy to download or easy to use help this site become more advantages compared to other SNS. This study found that users of Facebook perceived convenience when they used the site. From the result of this paper, in general uses perceived that Facebook was more easy to use compared to other SNS.

\subsection{Openness of Information}

Privacy was considered an important in SNS adoption (e.g. Gross \& Acquisti, 2005; Hodge, 2006). Whether users will disclose their information to other people is one of the issues discussed among them. Disclose some information may harm them (Hempel, 2005; Magid, 2006; Stafford, 2006).

This study found that males and females differed on the SNS adoption regarding to privacy issue. Females and younger people were more likely to keep their personal information only for their friends and relatives.

\subsection{Audience}

Is Facebook only for young people? The study found that there was a difference perception toward this issue between gender. Females perceived Facebook as for young people than males did. However, there was not significant difference for this issue between the two different age groups from the study. This finding helps filling the gap of literature.

\subsection{Making New Contacts}

Contacting with friends or making new friends such as joining a group are very common use for SNS. This study found similar results with many previous studies. Users also use SNS to meet new friends from different cultures. The study found that there were no differences on the perceptions of SNS adoption on making new contacts factor regarding gender and age variables.

\subsection{Acceptability}

Some religions may prohibit using SNS such as chatting or showing pictures. These issues came from the 
interviews used in the stage one of the study. Using Facebook is acceptable in my religion? and Facebook can harm the relationship (couples/friends) were the statements from the reponsdents. This study found that regarding to gender and age variables there were no significant differences between males and females and between younger people and old people in the acceptability issue. The average score for the acceptability was 3.5 from 5 scale, indicating that using Facebook was considered fine among Korean consumers.

\subsection{Conclusion}

In summary, this study examined the factors affecting the SNS adoption in South Korea. The result indicated nine factors namely involvement, usefulness, usage, trust, convenience, openness of information, audience, making new contacts, and acceptability. Using gender as a demographic factor, this study showed that males and females differed on their opinions toward using Facebook on involvement, usefulness, usage, openness of information and audience. Females were more involved in using Facebook than males were. Females perceived that Facebook was more useful, and they tended to have more activities on the site. However, females were more likely to keep their personal information only with friends and relatives compared to males.

This study also showed that young people were more involved and active in Facebook and perceived more usefulness of the SNS. This study showed that younger people used Facebook as a medium for communication with friends, and they were more likely to disclose their information to other people.

This study contributes to provide an examination for factors underlying Facebook adoption in South Korea. These underlying adoption characteristics can be applied to future studies or business practices. Because the results allowed us to understand Koreans' perceptions toward of using SNS, companies that conduct business online will get many benefits from this study. From this study, it showed that Korean consumers perceived benefits of using SNS. Companies may be able to find a way to expand their benefits through social network. Online marketing is still considered one of the most effective ways to build a good relationship with customers through SNS.

As a limitation, this study used only students as a sample. Students may not be a representative of population although they are one of the main targets of SNS users. Using another group such as working people may provide a different result. This can be done in a future study. In addition, with respect to future research in global arena, one interesting area is to find out whether people in different countries vary in their perceptions toward of using Facebook. The results will benefit international managers or companies.

\section{References}

Bimber, B. (2000). The gender gap on the internet. Social Science Quarterly, 81(3), 868-876.

Boyd, D. (2008). Why youth (heart) social network sites, the role of networked publics in teenage social life. In D. Buckingham (Ed), Youth, Identity, and Digital Media (pp. 119-1442). Cambridge, MA, MIT Press.

Bukowski, W. M., \& Hoza, B. (1989). Popularity and friendship: Issues in theory, measurement and outcome. In T. J. Brendt \& G.W. Ladd (Eds.), Peer Relationships in Child Development (pp. 15-45). New York: John Wiley \& Sons, Inc.

Daugherty, T., Eastin, M., \& Gangadharbatla, H. (2005). E-CRM: Understanding internet confidence and implications for customer relationship management. In Irvine Clark III \& Theresa Flaherty (Eds.), Advances in Electromic Marketing, (pp. 67-82). Harrisonburg, VA: James Madison University, Idea Group Publishing, Inc. http://dx.doi.org/10.4018/978-1-59140-321-0.ch004

DiMaggio, P., Hargittai, E., Celeste, C., \& Shafer, S. (2004). Digital equality: From unequal access to differentiated use. In K. Neckerman (Eds.), Social Inequality (pp. 355-400). New York: Russell Sage Foundation.

Donath, J., \& Boyd, D. (2004). Public displays of connection. BT Technology Journal, 2(4), 71-82. http://dx.doi.org/10.1023/B:BTTJ.0000047585.06264.cc

Ellison, N., Steinfield, C., \& Lampe, C. (2006). Spatially bounded online social networks and social capital: The role of Facebook. Paper Presented at the Annual Meeting of the International Communication Association, Dresden.

Gross, R., \& Acquisti, A. (2005). Information revelation and privacy in online social networks (The Facebook Case). Proceedings of ACM Workshop on Privacy in the Electronic Society. Alexandria, VA: Association for Computing Machinary, 71-80. http://dx.doi.org/10.1145/1102199.1102214 
Hair, J. F., Anderson, R. E., Tatham, R. L., \& Black, W. C. (1998). Multivariate Data Analysis (5th ed.). Upper Saddle River, NJ: Prentice-Hall.

Hall, J., \& Cooper, J. (1991). Gender, experience, and attributions to the computer. Journal of Educational Computing Research, 7(1), 51-60. http://dx.doi.org/10.2190/TVHG-MYBV-GEFW-B4J0

Hargittai, E. (2008). Whose space? Differences among users and non-users of social network sites. Journal of Computer-Mediated Communication, 13(1), 276-297. http://dx.doi.org/10.1111/j.1083-6101.2007.00396.x

Hargittai, E., \& Litt, E. (2011). The tweet smell of celebrity success: Explaining variation in Twitter adoption among a diverse group of young adults. New Media Society, Sage publications. Retrieved from $\mathrm{http}: / / \mathrm{nms}$.sagepub.com/content/13/5/824

Hargittai, E., \& Shafer, S. (2006). Differences in actual and perceived online skills: The role of gender. Social Science Quarterly, 87(2), 432-448. http://dx.doi.org/10.1111/j.1540-6237.2006.00389.x

Hempel, J. (2005). Protecting your kids form cyber-predators. Business Week.

Hodge, M. J. (2006). The fourth amendment and privacy issues on the "New" internet Facebook.com and MySpace.com. Southern Illinois University Law Journal, 31, 95-123.

Howard, P. N., Rainie, L., \& Jones, S. (2001). Days and nights on the Internet: The impact of a diffusing technology. American Behavioral Scientist, 45(3), 383-404.

Jackson, L. A., Ervin, K. S., Gardner, P. D., \& Schmitt, N. (2001). Gender and the internet: Women communicating and men searching. Sex Roles, 44(5/6), 363-379. http://dx.doi.org/10.1023/A:1010937901821

Joinson, A. N. (2008). Looking at, looking up, or keeping up with people? Motives and uses of Facebook. Proceeding paper at Online Social Networks, Florence, Italy.

Lenhart, A., \& Madden, M. (2007). Social networking websites and teens: An overview. Pew Internet and American Life Project Report. Retrieved from //www.pewinternet.org/PDF/r/198/report_display.asp

Lin, Trisha T. C., Chiu, Vicki C. H., \& Lim W. (2011). Factors affecting the adoption of social setwork sites: Examing four adopter categories of Singapore's working adults. Asian Journal of Communication, 21(3), 221-242. http://dx.doi.org/10.1080/01292986.2011.559256

Livingstone, S., \& Helsper, E. (2007). Gradations in digital inclusion: Children, young people, and the digital divide. New Media and Society, 9, 671-696. http://dx.doi.org/10.1177/1461444807080335

Madden, M., \& Raine, L. (2003). American Online Pursuits. Pew Internet and American Life Project Report. Retrieved from http://www. Pewinternet.org/PDF/r/182/report_display.asp?r=106

Magid, L. (2006). Protect Kids on MySpace. CBS News. Retrieved from http://www.cbsnews.com/stories/2006/02/03/scitech/panswer/main1277909.shtml

Mansumitrchai, S., \& Chiu, C. (2012). Adoption of internet banking in UAE: Factors underlying the adoption characteristics. International Journal of Management and Marketing Research, 5(1), 103-115.

Mansumitrchai, S., \& Malkawi, H. (2011). Factors underlying the adoption of online banking by Mexican Consumers. International Journal of Business and Management, 6(9), 155-169. http://dx.doi.org/10.5539/ijbm.v6n9p155

Mossberger, K., Tolbert, C. J., \& Stansbury, M. (2003). Virtual inequality: Beyond the digital divide. Washington, D.C.: Georgetown University Press.

Ono, H., \& Zavodny, M. (2003). Gender and the internet. Social Science Quarterly, 84(1), 111-121. http://dx.doi.org/10.1111/1540-6237.t01-1-8401007

Parkhurst, J. T., \& Hopmeyer, A. (1998). Sociometric popularity and peer-perceived popularity: Two distinct dimensions of peer status. The Journal of Early Adolescence, 18(2), 125-144. http://dx.doi.org/10.1177/0272431698018002001

Sheldon, P. (2008). Student favorite: Facebook and motives for its use. Southwestern Mass Communication Journal, 23(2), 39-53.

Stafford, R. (2006). Why parents must mind MySpace. Retrieved from http://www/msnbc.msn.com/id/11064451/

Van Dijk, J. A. G. M. (2005). The deepening divide. London: Sage Publications.

Watkins, S. C. (2009). The young and the digital: What the migration to social network sites, games, and 
anytime, anywhere media means for our future. Boston, MA: Beacon Press.

Wellman, B., \& Gulia, M. (1999). The network basis of social support: A network is more than the sum of tts ties. In Wellman B (Eds), Networks in the Global Village. Boulder, CO: Westview Press. 